\title{
Article \\ Genetic Characterization of the Tetracycline-Resistance Gene tet(X) Carried by Two Epilithonimonas Strains Isolated from Farmed Diseased Rainbow Trout, Oncorhynchus mykiss in Chile
}

\author{
Christopher Concha ${ }^{1}$, Claudio D. Miranda ${ }^{1,2, *}$, Javier Santander ${ }^{3}\left(10\right.$ and Marilyn C. Roberts ${ }^{4}$ \\ 1 Laboratorio de Patobiología Acuática, Departamento de Acuicultura, Universidad Católica del Norte, \\ Coquimbo 1780000, Chile; christopher.concha@ucn.cl \\ 2 Centro AquaPacífico, Coquimbo 1780000, Chile \\ 3 Marine Microbial Pathogenesis and Vaccinology Laboratory, Department of Ocean Sciences, Memorial \\ University of Newfoundland, St. John's, NL A1C 5S7, Canada; jsantander@mun.ca \\ 4 Department of Environmental and Occupational Health Sciences, School of Public Health, University of \\ Washington, 4225 Roosevelt Way NE, Suit \#100, Seattle, WA 98105, USA; marilynr@u.washington.edu \\ * Correspondence: cdmirand@ucn.cl; Tel.: +56-512209762
}

check for updates

Citation: Concha, C.; Miranda, C.D.; Santander, J.; Roberts, M.C. Genetic Characterization of the TetracyclineResistance Gene tet $(\mathrm{X})$ Carried by Two Epilithonimonas Strains Isolated from Farmed Diseased Rainbow Trout, Oncorhynchus mykiss in Chile. Antibiotics 2021, 10, 1051. https:// doi.org/10.3390/antibiotics10091051

Academic Editor: Antony T. Vincent

Received: 2 August 2021

Accepted: 13 August 2021

Published: 29 August 2021

Publisher's Note: MDPI stays neutral with regard to jurisdictional claims in published maps and institutional affiliations.

Copyright: (c) 2021 by the authors. Licensee MDPI, Basel, Switzerland. This article is an open access article distributed under the terms and conditions of the Creative Commons Attribution (CC BY) license (https:// creativecommons.org/licenses/by/ $4.0 /)$.

\begin{abstract}
The main objective of this study was to characterize the tet $(\mathrm{X})$ genes, which encode a monooxygenase that catalyzes the degradation of tetracycline antibiotics, carried by the resistant strains FP105 and FP233-J200, using whole-genome sequencing analysis. The isolates were recovered from fin lesion and kidney samples of diseased rainbow trout Oncorhynchus mykiss, during two Flavobacteriosis outbreaks occurring in freshwater farms located in Southern Chile. The strains were identified as Epilithonimonas spp. by using biochemical tests and by genome comparison analysis using the PATRIC bioinformatics platform and exhibited a minimum inhibitory concentration (MIC) of oxytetracycline of $128 \mu \mathrm{g} / \mathrm{mL}$. The tet $(\mathrm{X})$ genes were located on small contigs of the FP105 and FP233-J200 genomes. The sequences obtained for the tet $(\mathrm{X})$ genes and their genetic environment were compared with the genomes available in the GenBank database of strains of the Chryseobacterium clade belonging to the Flavobacterium family, isolated from fish and carrying the tet $(\mathrm{X})$ gene. The Tet $(\mathrm{X})$ proteins synthesized by the Chilean Epilithonimonas strains showed a high amino acid similarity (range from $84 \%$ to $100 \%$ ), with the available sequences found in strains belonging to the genus Chryseobacterium and Flavobacterium isolated from fish. An identical neighborhood of tet $(\mathrm{X})$ genes from both Chilean strains was observed. The genetic environment of tet $(\mathrm{X})$ observed in the two strains of Epilithonimonas studied was characterized by the upstream location of a sequence encoding a hypothetical protein and a downstream located alpha/beta hydrolase-encoding gene, similar to the observed in some of the tet $(\mathrm{X})$ genes carried by Chryseobacterium and Flavobacterium strains isolated from fish, but the produced proteins exhibited a low amino acid identity (25-27\%) when compared to these synthesized by the Chilean strains. This study reports for the first time the carriage of the tet $(X)$ gene by the Epilithonimonas genus and their detection in fish pathogenic bacteria isolated from farmed salmonids in Chile, thus limiting the use of therapies based on oxytetracycline, the antimicrobial most widely used in Chilean freshwater salmonid farming. This results suggest that pathogenic strains of the Chryseobacterium clade occurring in Chilean salmonid farms may serve as important reservoirs of tet $(\mathrm{X})$ genes.
\end{abstract}

Keywords: tet $(\mathrm{X})$; Epilithonimonas; salmon farming; fish pathogen; tetracycline resistance; aquaculture; Chile

\section{Introduction}

In Chilean salmon freshwater farms, the high prevalence of bacterial infections, such as Flavobacteriosis mainly caused by the pathogen Flavobacterium psychrophilum, has stimulated the use of important amounts of antimicrobials [1-3]. In 2020, the Chilean salmonid 
farming industry used 379.6 tons to produce a biomass of 1,075,896 tons of harvested fish, of which $2.44 \%$ was used in freshwater Chilean salmonid farms [4]. Oxytetracycline was the most used antimicrobial in freshwater Chilean salmonid farming during 2020, accounting for $79.52 \%$ of antimicrobials administered in this environment [4], and from these, $38.26 \%$ was used for the treatment of Flavobacteriosis episodes, in which external signs of disease are commonly treated through a bath with oxytetracycline [2].

Aquaculture settings have been suggested as environments with a high diversity of tet genes, encoding for tetracycline resistance $[5,6]$, perhaps due to the wide use of oxytetracycline to treat fish diseases [7]. Thus, the persistence and enrichment of tet genes in the aquaculture environments can be significantly enhanced by the administration of oxytetracycline-based therapies, prompting the need of a continuous surveillance.

Previously, several studies demonstrated an important occurrence of oxytetracyclineresistant bacteria in Chilean land- and lake-based farms associated with Chilean freshwater farming [8,9]. It have previously been reported the carriage of several tet genes, such as tet( $\mathrm{A}), \operatorname{tet}(\mathrm{B}), \operatorname{tet}(\mathrm{E}), \operatorname{tet}(\mathrm{H}), \operatorname{tet}(\mathrm{L}), \operatorname{tet}(34), \operatorname{tet}(35)$, and tet(39) by various bacterial species recovered from various Chilean aquaculture sources, including reared fish, pelletized feed, and water and sediment from lake-based farms [10,11]. In a more recent study, the encoding-resistance genes tet $(\mathrm{A}), \operatorname{tet}(\mathrm{B}), \operatorname{tet}(\mathrm{C}), \operatorname{tet}(\mathrm{L}), \operatorname{tet}(\mathrm{M}), \operatorname{tet}(\mathrm{S}), \operatorname{tet}(\mathrm{W})$, and tet $(\mathrm{X})$ were reported in various points in riverine waters located upstream and downstream from the discharge of effluents of various freshwater rainbow trout (Oncorhynchus mykiss) rearing farms in Chile [7]. As noted in the article, the most common disease occurring in the five studied trout farms was Flavobacteriosis causing a $3-4 \%$ mortality in each farm.

Most of the known tet genes confer resistance to tetracyclines by encoding for efflux proteins (33 genes), whereas a smaller number of tet genes conferring resistance to tetracyclines by encoding ribosomal protection proteins (12 genes) or for enzymes that chemically modify tetracycline (13 genes) have been currently reported (http: / faculty.washington. edu/marilynr/, accessed on 10 August 2021).

The tet $(\mathrm{X})$ gene encodes a NADP-dependent monooxygenase that catalyzes the degradation of tetracycline antibiotics, including tigecycline [12-14]. It is well-known that tet $(X)$-carrying bacteria exhibit high levels of resistance to all clinical important tetracyclines [15], but until now, no studies reporting the occurrence of this gene in bacteria isolated from Chilean salmonid farms are available. In only one study it was demonstrated the occurrence of tet $(\mathrm{X})$ genes in pathogenic fish bacteria belonging to the Flavobacterium family, identified as Chryseobacterium balustinum (identity: 95.5\%) and recovered from rainbow trout in the UK [16].

Epilithonimonas is a bacterial genus belonging to the Chryseobacterium clade, thus closely related to the bacterial genus Chryseobacterium, the second largest genus in the Flavobacteriaceae family [17,18]. Epilithonimonas sp. FP211-J200 is the first representative of this genus associated with fish diseases [19], but tet $(X)$ genes have never been previously reported in this genus. The main aim of the study was to characterize tet $(X)$ genes and their genetic background carried by two Epilithonimonas strains isolated from diseased fishes from two Chilean freshwater salmonid farms.

\section{Results}

\subsection{Phenotypic Characterization}

The bacterial strains FP105 and FP211-J200 showed the phenotypic characteristics typical of members of the Chryseobacterium clade belonging to the Flavobacterium family. Strains FP105 and FP211-J200 were found to be Gram-negative, rod-shaped, non-motile, positive for production of oxidase, indole and catalase, reduction of nitrate to nitrite and hydrolysis of aesculin, negative for acid production from glucose and able to form flexirubin-type pigments. When grown on TYES agar, the colonies were circular, smooth, convex and bright orange with diameters from 1.5 to $2.5 \mathrm{~mm}$ (Figure 1). Both strains were able to grow on R2A and Tryptone Soy agar plates, but not on MacConkey agar. Growth of strains occurred at 15 and $28^{\circ} \mathrm{C}$, but not at 37 and $42{ }^{\circ} \mathrm{C}$, and cannot tolerate $2 \% \mathrm{NaCl}$. 

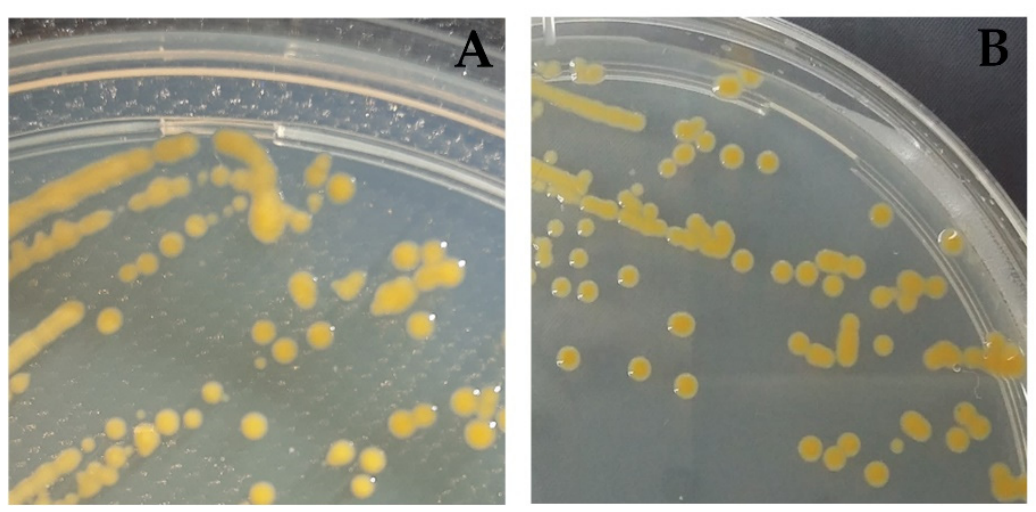

Figure 1. Colony morphotypes of the Epilithonimonas strains recovered from diseased rainbow trout from Chilean farms grown on TYES agar: (A) FP105; (B) FP211-J200.

The API ZYM profiles of the FP105 and FP211-J200 strains are presented in Table 1, showing the capacity of both isolates to produce the enzymes alkaline phosphatase, esterase (C4), lipase (C8), leucine arylamidase, valine arylamidase, acid phosphatase, and naphtholAS-BI-phosphohydrolase, whereas only FP211-J200 strain was able to produce lipase (C14) and cystine arylamidase.

Table 1. Enzymatic properties of the Epilithonimonas FP105 and FP211-J200 strains by using the API ZYM system (BioMerieux).

\begin{tabular}{|c|c|c|}
\hline \multirow{2}{*}{ Enzyme } & \multicolumn{2}{|c|}{ Activity } \\
\hline & FP105 & FP211-J200 \\
\hline Control & Negative & Negative \\
\hline Alkaline phosphatase & Positive & Positive \\
\hline Esterase (C4) & Positive & Positive \\
\hline Esterase lipase (C8) & Positive & Positive \\
\hline Lipase (C14) & Negative & Positive \\
\hline Leucine arylamidase & Positive & Positive \\
\hline Valine arylamidase & Positive & Positive \\
\hline Cystine arylamidase & Negative & Positive \\
\hline Trypsin & Negative & Negative \\
\hline$\alpha$-chymotrypsin & Negative & Negative \\
\hline Acid phosphatase & Positive & Positive \\
\hline Naphthol-AS-BI-phosphohydrolase & Positive & Positive \\
\hline$\alpha$-galactosidase & Negative & Negative \\
\hline$\beta$-galactosidase & Negative & Negative \\
\hline$\beta$-glucoronidase & Negative & Negative \\
\hline$\alpha$-glucosidase & Negative & Negative \\
\hline$\beta$-glucosidase & Negative & Negative \\
\hline$N$-acetyl- $\beta$-glucosaminidase & Negative & Negative \\
\hline$\alpha$-mannosidase & Negative & Negative \\
\hline$\alpha$-fucosidase & Negative & Negative \\
\hline
\end{tabular}

\subsection{Bacterial Identification}

The whole genome sequences of FP105 and FP211-J200 strains were compared with several whole genome sequences currently available for the related members of the Chryseobacterium clade. The results are presented as a phylogenetic dendrogram, as is depicted in Figure 2 showing that both Chilean strains are members of the genus Epilithonimonas, observing that Chilean strains are genetically most closely related to the Epilithonimonas lactis strain LMG24401 isolated from raw cow's milk in Israel [20]. 




Figure 2. Phylogenetic tree based on the whole genome sequences, showing the relationship between the Chilean Epilithonimonas strains (FP105 and FP211-J200) and closely related taxa within the Chryseobacterium clade. Tree was constructed using the patric server (https:/ / patricbrc.org/app/PhylogeneticTree, accessed on 12 July 2021). A total of 100 single-copy genes found for 46 genomes and both amino acid and nucleotide sequences were used for each gene. Empedobacter brevis NBRC 14943 was used as an outgroup. Accession numbers of each sequence are shown in parentheses. Red asterisks $\left({ }^{*}\right)$ are included to highlight genomes harboring the tet $(\mathrm{X})$ gene.

\subsection{Minimum Inhibitory Concentrations (MICs)}

Both the MIC values of oxytetracycline of FP105 and FP211-J200 strains were $128 \mu \mathrm{g} / \mathrm{mL}$, whereas reference strains Escherichia coli (E. coli) ATCC 25922 and Aeromonas salmonicida ATCC 33658 used for quality controls exhibited MIC values of oxytetracycline of 0.5 and $0.25 \mu \mathrm{g} / \mathrm{mL}$, respectively, in agreement with the values recommended by CLSI [21]. 


\subsection{Molecular Analysis of tet(X)}

When the publicly available genomes of other genera belonging to the Flavobacteriaceae family were investigated, among the genomes of strains deposited in GenBank belonging to Flavobacterium, Chryseobacterium, and Empedobacter genus. They were isolated from fishes, and only three genomes of Flavobacterium spp. and six genomes of Chryseobacterium spp. were found to harbor the tet $(\mathrm{X})$ gene.

Tet $(X)$ was detected in contigs 80 (5749 bp) and 54 (5763 bp) of FP211-J200 and FP105 genomes, respectively, and were identical at nucleotide and amino acid sequence level (identity of $100 \%$ ) to each other. As shown in Table 1, the amino acid sequence identity of Tet $(X)$ protein produced by Epilithonimonas strains exhibited a $100 \%$ identity with those synthesized by the Chryseobacterium strains (SNU WT5 and SNU WT7) from South Korea $[22,23]$. $\operatorname{Tet}(X)$ proteins from Chilean strains showed an approximately $84 \%$ identity with the Tet $(\mathrm{X})$ of Chryseobacterium from the UK (MOF25P and BGARF1) [16], Turkey (C2), and Spain (701B-08) [24,25], Flvobacterium kayseriense from Turkey (F-47 and F-380) [26], and Flavobacterium plurextorum from Spain (CCUG 60112) [27,28]. All of these strains were isolated from fish, and their whole genomes are currently included in the GenBank database (Table 2).

As observed in Figure 3, the surface structure of $\operatorname{Tet}(X)$ protein first described in Bacteroides fragilis (Figure 3A) and used as the structure reference (control) showed a high similarity with $\operatorname{Tet}(\mathrm{X})$ proteins synthesized by the Chilean Epilithonimonas strains and Chryseobacterium strains from South Korea (Figure 3B). However, they showed an important number of differences with the $\operatorname{Tet}(\mathrm{X})$ protein structures produced by the Chryseobacterium strains from the UK (Figure 3C) and Flavobacterium strains from Turkey (Figure 3D) and Spain (Figure 3E) at the substrate binding domain, FAD (flavin adenine dinucleotide)binding domain, and helix bridge.

The above is mostly explained, because $\operatorname{Tet}(\mathrm{X})$ proteins synthesized by the Chilean Epilithonimonas and South Korean Chryseobacterium strains exhibited only two amino acid substitutions with the sequence of $\operatorname{Tet}(\mathrm{X})$ protein produced by B. fragilis (Figure S1, Supplementary Data). In contrast, there were a number of amino acid substitutions (64 or 67) between the sequences of the $\operatorname{Tet}(X)$ protein synthesized by the $B$. gracilis strain, and the sequences of the $\operatorname{Tet}(\mathrm{X})$ proteins synthesized by the Chryseobacterium strains from the UK, Turkey, and Spain and the Flavobacterium strains (Figure S1, Supplementary Data).

Otherwise, the alignment of the amino acid sequences of $\operatorname{Tet}(X)$ from the studied strains did not shown substitutions in the amino acid sequences of the putative substrateloading cavity composed of FAD-interactive residues and tetracycline-binding residues, thus not affecting their antimicrobial inactivation activity (Figure S1, Supplementary Data).

The genetic environment of tet $(\mathrm{X})$ genes of Epilithonimonas sp. FP105 and FP211-J200 strains was characterized by the upstream location of a sequence encoding an hypothetical protein, whereas the downstream of the tet $(X)$ gene was detected by a gene encoding an alpha/beta hydrolase (Figure 4). When the neighborhood of the tet $(X)$ genes carried by both Chilean Epilithonimonas strains was compared to the other fish Flavobacteriaceae tet $(\mathrm{X})$, the genetic surroundings of tet $(\mathrm{X})$ genes carried by the Epilithonimonas strains were very different to those of the South Korean Chryseobacterium strains. The Chryseobacterium strains carried a $\ln u(\mathrm{~F})$ gene encoding a lincosamide nucleotidyltransferase protein at the upstream location and a downstream location of a gene encoding a class D $\beta$-lactamase (SNU WT5). While both carried the ere $(D)$ gene, they were responsible for erythromycin resistance (SNU WT7) found in different locations (Figure 4).

The same upstream and downstream flanking genes of tet $(\mathrm{X})$ genes carried by the Chilean strains were observed in the tet $(\mathrm{X})$ genes carried by the Chryseobacterium spp. strains from UK, Turkey, and Spain. While the tet $(\mathrm{X})$ genes carried by the Flavobacterium strains also exhibited an upstream flanking gene encoding an hypothetical protein, they had different downstream flanking genes (Figure 4). 

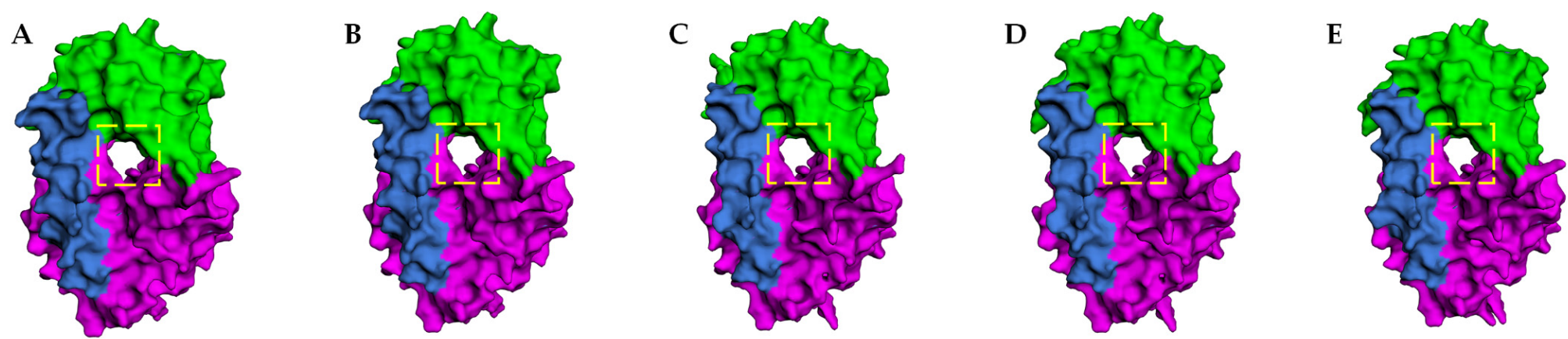

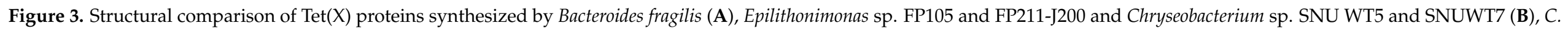

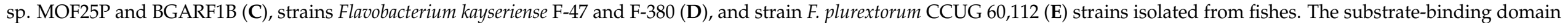
(light green), FAD-binding domain (pink), and C-terminal helix (blue) are displayed, while the open substrate-loading channel is marked by a yellow dotted box.

Table 2. Similarity of nucleotide and amino acid sequences of Tet $(\mathrm{X})$ synthesized by Flavobacteriaceae strains isolated from fishes and Tet(X) produced by Bacteroides fragilis (control).

\begin{tabular}{|c|c|c|c|c|c|c|c|c|c|c|c|c|}
\hline \multirow{2}{*}{ Strain } & \multicolumn{12}{|c|}{ Percentage of Nucleotide/Amino Acid Similarity * (\%) } \\
\hline & Control & FP105 & FP211-J200 & SNU WT5 & SNU WT7 & MOF25P & BGARF1 & $\mathrm{C} 2$ & 701B-08 & F-47 & F-380 & CCGU \\
\hline Control & $100 / 100$ & $99.83 / 99.48$ & $99.83 / 99.48$ & $99.83 / 99.48$ & $99.83 / 99.48$ & $86.00 / 83.20$ & $86.00 / 83.20$ & $85.91 / 83.20$ & $85.82 / 83.20$ & $83.59 / 82.69$ & $83.59 / 82.69$ & $83.76 / 83.20$ \\
\hline FP105 & & $100 / 100$ & $100 / 100$ & $100 / 100$ & $100 / 100$ & $87.25 / 84.66$ & $87.25 / 84.66$ & $87.16 / 84.66$ & $87.07 / 84.66$ & $84.78 / 84.13$ & $84.78 / 84.13$ & $84.96 / 84.66$ \\
\hline SNU WT5 & & & & $100 / 100$ & $100 / 100$ & $87.25 / 84.66$ & $87.25 / 84.66$ & $87.16 / 84.66$ & $87.07 / 84.66$ & $84.78 / 84.13$ & $84.78 / 84.13$ & $84.96 / 84.66$ \\
\hline SNU WT7 & & & & & $100 / 100$ & $87.25 / 84.66$ & $87.25 / 84.66$ & $87.16 / 84.66$ & $87.07 / 84.66$ & $84.78 / 84.13$ & $84.78 / 84.13$ & $84.96 / 84.66$ \\
\hline MOF25P & & & & & & $100 / 100$ & $100 / 100$ & $99.91 / 100$ & $99.82 / 100$ & $92.61 / 93.92$ & $92.61 / 93.92$ & $90.85 / 91.27$ \\
\hline BGARF1 & & & & & & & $100 / 100$ & $99.91 / 100$ & $99.82 / 100$ & $92.61 / 93.92$ & $92.61 / 93.92$ & $90.85 / 91.27$ \\
\hline 701B-08 & & & & & & & & & $100 / 100$ & $92.44 / 93.92$ & $92.44 / 93.92$ & $90.68 / 91.27$ \\
\hline $\mathrm{F}-47$ & & & & & & & & & & $100 / 100$ & $100 / 100$ & $92.00 / 92.06$ \\
\hline F-380 & & & & & & & & & & & $100 / 100$ & $92.00 / 92.06$ \\
\hline CCUG 60112 & & & & & & & & & & & & $100 / 100$ \\
\hline
\end{tabular}

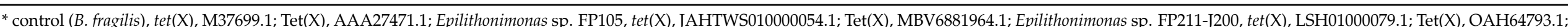



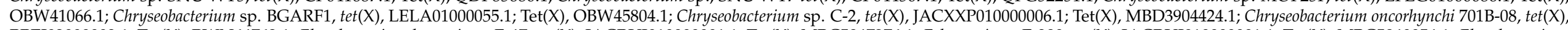

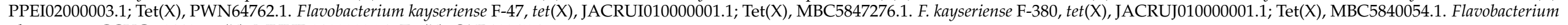
plurextorum CCUG 60112, tet(X), MUHD01000006.1; Tet(X), OXB10245.1. 
SNU WT5

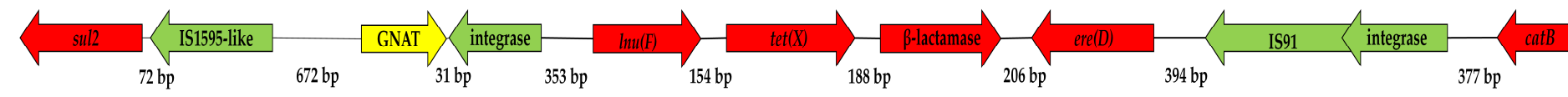

SNU WT7

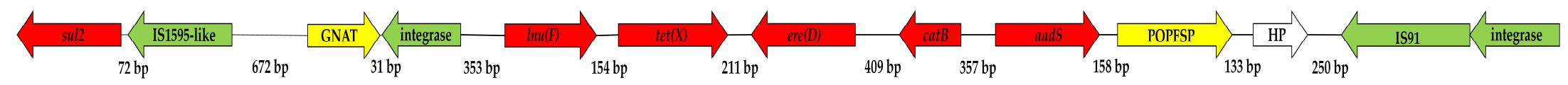

CCUG 60112

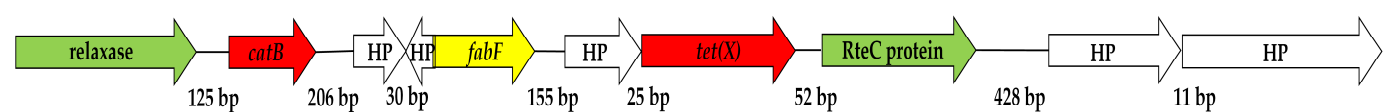

F-47

F-380

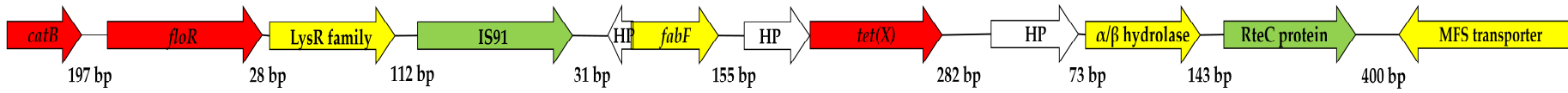

$C-2$

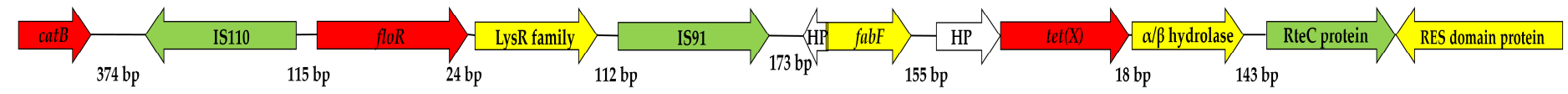

701B-08



MOF25P

BGARF1

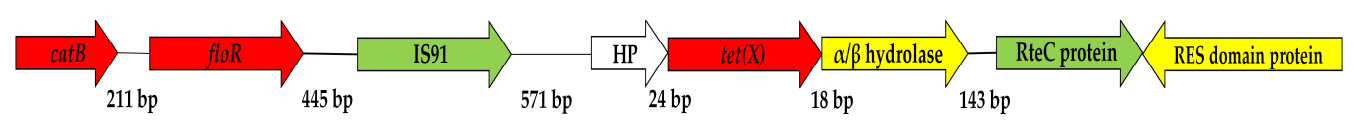

FP211-J200

FP105

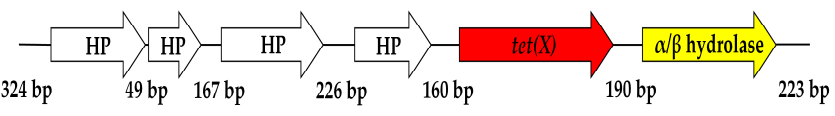

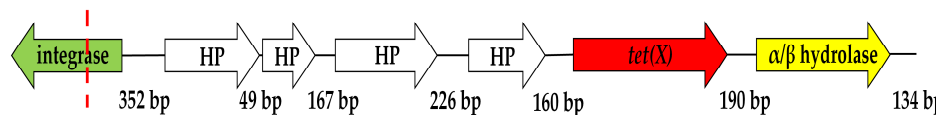

$$
\begin{aligned}
& 500 \mathrm{bp}
\end{aligned}
$$

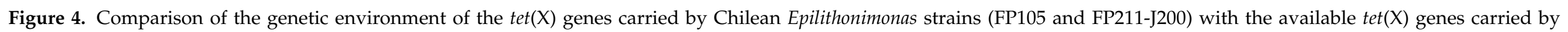

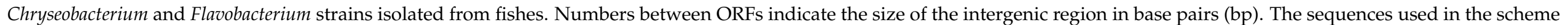

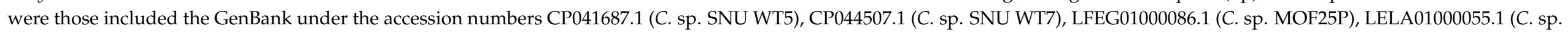

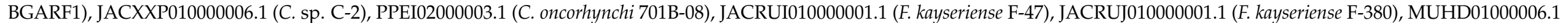

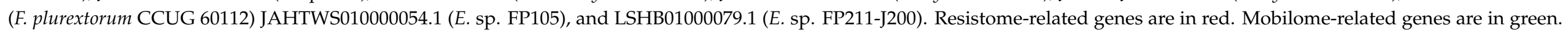
Hypothetical proteins (HP) are in white. Other genes are in yellow. 
The Chilean strains showed a very low amino acid identity to the flanking hypothetical proteins detected in the Chryseobacterium, Flavobacterium kayseiense (F. kayseriense; $26.51 \%$ ), and Flavobacterium plurextorum (25.30\%) strains. Otherwise, the genes encoding the hypothetical proteins carried by the Chryseobacterium and Flavobacterium strains had an amino acid identity of more than $90 \%$ (Table S1, Supplementary Data).

As is shown in Figure 4, four Chryseobacterium spp. (MOF25P, BGARF1, C-2, and 701B-08) and two F. kayseriense (F-47 and F-380) strains also carried a downstream located gene encoding an alpha/beta hydrolase (Figure 3). However, Chilean strains showed a very low amino acid identity to the flanking alpha/beta hydrolase sequences detected in the Chryseobacterium (27.13\%) and F. kayseriense (27.67\%) strains. All of the hydrolase genes carried by the Chryseobacterium strains shared a 100\% amino acid identity between themselves, as was observed between the same genes carried by the F. kayseriense strains (Table S2, Supplementary Data).

\section{Discussion}

\subsection{Bacterial Identification}

Many representatives belonging to the Flavobacteriaceae family have a very relevant role as fish pathogens, as was exhaustively described [29,30]. The genus Chryseobacterium has been frequently isolated as the causative agent of disease ocurring in freshwater fish and particularly rainbow trout diseases, including C. viscerum, C. oncorhynchae, C. tructae, C. shigense, C. chaponense, $C$. piscicola species $[24,31,32]$. Other members of the Flavobacteriaceae family have been previously isolated from diseased farmed salmonids in Chile [33-35].

It is not uncommon to misidentify bacteria as F. psychrophilum as occurs with the studied strains, which could be due to the fact that they be correctly identified as Epilithonimonas sp., a member of the Chryseobacterium clade, shown in this study [36,37].

This misidentification is very relevant considering that F. psychrophilum species does not carry specific genes for resistance to tetracyclines, as occurs with pathogenic strains of fish and humans belonging to the Chryseobacterium clade, including several species belonging to the Chryseobacterium, Empedobacter, and Riemerella genus, among others, which have been reported to carry the tet $(X)$ gene [38-42]. As a result of this, it has been hypothesized that the Flavobacteriaceae family could be a potential ancestral source of the tigecycline-resistance gene tet $(\mathrm{X})$, as was recently claimed [43]. Thus, the detection of genes encoding for tetracycline resistance in fish pathogenic bacteria is of concern for the sustainability of this industry.

\subsection{Detection of tet $(X)$ Genes}

It has been demonstrated that using culture-independent methods, water samples taken from fish farms with recent oxytetracycline use have significantly higher frequencies of tet genes than water from farms without recent oxytetracycline therapies exceeding by more than two-fold that of untreated farms [44].

Furthermore, the occurrence of tetracycline-resistance encoding genes in aquacultureimpacted environments is frequent, as was observed in studies showing that $57.14 \%$ of the total resistant bacteria recover from aquaculture environments [45]. All 108 resistant strains isolated from aquaculture ponds in China were positive for a tet gene [46], which persisted at aquaculture farms even in the absence of a selection pressure [47]. Xiong et al. [48] found a high relative abundance $\left(10^{-5}\right.$ to $10^{-3}$ of gene copies/16S ribosomal RNA (rRNA) gene copies) of various tet genes, including tet $(\mathrm{X})$ in sediment samples from fish ponds without antimicrobial usage. They concluded that detected antimicrobials, such as oxytetracycline and doxycycline, were introduced by applied organic wastes from terrestrial animals. The authors suggested that sediments are the main reservoirs of tetracycline resistance genes in aquaculture environments in China. Another study has shown that farmed fish feces are a relevant source of tetracycline resistance genes in the farm sediments, despite the absence of antibiotic treatments at the studied farms [49]. 
In a recent article [50], the authors performed a whole-genome sequencing analysis of the Chryseobacterium aquaticum strain C-174, isolated from diseased farmed rainbow trout in Turkey, reporting this strain carries many tetracycline-resistance genes, including tet(32), tet(60), tet $(\mathrm{T})$, tet $(\mathrm{X})$, and tet $(\mathrm{W})$. However, when the $\mathrm{C}-174$ genome was further analyzed, we confirmed that all of these genes, and other reported antimicrobial-resistance genes were misidentified, not corresponding to antimicrobial-resistance genes. The tet $(X)$ sequence (NMR 36027.1) has only a $28 \%$ identity with the tet $(X)$ sequence included in the GenBank database, whereas it has a $99 \%$ identity with other flavin-dependent monooxygenases which do not belong to the Tet(X) group (WP_050378416.1).

It must be noted that among all tet $(\mathrm{X})$ genes reported in flavobacteriaceae strains from fish, only in this study, it was confirmed that the detected tet $(\mathrm{X})$ genes conferred the tetracycline-resistance phenotype, considering that both Epilithonimonas strains showed an MIC of oxytetracycline of $128 \mu \mathrm{g} / \mathrm{mL}$, which is within the expected level of resistance to oxytetracycline mediated by the $\operatorname{Tet}(\mathrm{X})$ activity. This value is in agreement with previous studies in which tet $(\mathrm{X})$ genes heterologously expressed by E. coli transconjugants harboring recombinant plasmids exhibited MIC values of 128-256 $\mu \mathrm{g} / \mathrm{mL}[12,40,51,52]$.

\subsection{Molecular Analysis of tet $(X)$}

The tet $(X)$ genes carried by the Chilean strains were $99.83 \%$ identcal to the wildtype (WT) tet $(\mathrm{X})$ gene, which was first recovered in Bacteroides fragilis [53], and only two mutations (A280G and G1077C) were detected in the tet (X) genes carried by the Chilean Epilithonimonas strains resulting in amino acid substitutions at the corresponding sites (K94E and M359I), (Figure S1). These two mutatios were previously reported in a tet(X) variant carried by an Empedobacter falsenii strain isolated from a chinese patient [41]. The authors demonstrated that both amino acids are located far from the active site regions, thus not affecting the activity of this Tet $(X)$ protein.

Important differences in the genetic neighborhood of tet $(X)$ genes carried by the Chilean strains, when compared to the other tet(X)-carrying strains isolated from fishes, were observed. It must be noted that all Chryseobacterium and Flavobacterium strains analyzed in the study carried the catB gene, encoding for a chloramphenicol acetyltransferase in the tet $(X)$ neighborhood, whereas this gene was absent in the genome of Chilean Epilithonimonas strains.

In addition, the insertion sequence IS91 was detected in the genetic environment of the majority of the analyzed strains, with the only exception of the Chilean strains and F. plurextorum. In addition, the tet $(\mathrm{X})$ gene in Bacteroides fragilis was found to be inserted in the transposon Tn4400, with an upstream location of the erythromycin-resistance gene ermF [53], very different from what was observed in the strains in this study.

This is the first report of a tet $(\mathrm{X})$ gene detected in pathogenic species belonging to the Flavobacteriaceae family in Chilean aquaculture and prompts the necessity to investigate the carriage of this gene by bacteria associated to Chilean salmonid farms and farmed salmonid microbiota, considering that mobilome elements such as ISCR2, IS26, and many conjugative and mobilizable plasmids could play an essential role in the acquisition and dissemination of $\operatorname{tet}(\mathrm{X})$ genes in natural reservoirs [54]. Furthermore, the potential role of pathogenic strains belonging to the Flavobacteriales occurring in Chilean salmonid farms as reservoirs of tet $(\mathrm{X})$ genes must be elucidated.

\section{Materials and Methods}

\subsection{Bacterial Strains}

The bacterial strains FP105 and FP233-J200 isolated from fin lesion (FP105) and kidney (FP223-J200) of diseased rainbow trout Oncorhynchus mykiss positively diagnosed with Flavobacteriosis sampled from two freshwater Chilean farms located in the South of Chile (Llanquihue Lake and Cude River, respectively) were studied. Strains were isolated in the fish pathological diagnostic laboratory ADL Diagnostics and sent to the Aquatic Pathobiology Lab of the Universidad Católica del Norte. The strains were purified using 
Tryptone-Yeast Extract Salt (TYES) agar [55] and stored at $-85^{\circ} \mathrm{C}$ in CryoBank ${ }^{\mathrm{TM}}$ vials (Mast Diagnostica, Reinfeld, Germany). Strains were grown in TYES agar at $25^{\circ} \mathrm{C}$ for $24 \mathrm{~h}$ prior to use (Figure 3).

\subsection{Phenotypic Characterization}

The phenotypic tests of Gram staining, cell morphology, colony morphology grown onto TYES agar, and oxidation/fermentation $(\mathrm{O} / \mathrm{F})$ of glucose were determined according to the procedures described in Buller [56]. Furthermore, several key characteristics for the description of bacterial strains belonging to the Flavobacteriaceae family [57], such as production of oxidase and catalase, hydrolysis of aesculin and gelatin, reduction of nitrate to nitrite, indole production, production of flexirubin-type pigment, growth at $25^{\circ} \mathrm{C}$ on R2A (Becton-Dickinson, Sparks, MD, USA), MacConkey (Becton-Dickinson, Sparks, MD, USA), Trypticase Soy (TSA, Becton-Dickinson, Sparks, MD, USA) agar, and in Brain Heart Infusion (BHI, Becton-Dickinson, Sparks, MD, USA) broth added with 1.0, 2.0, 3.0, 4.5, and $6.5 \% \mathrm{NaCl}$ were performed using procedures as previously described [56,58]. In addition, growth at $15,25,30,37$, and $42{ }^{\circ} \mathrm{C}$ in a BHI broth was assayed.

Other enzymatic activities of FP105 and FP223-J200 strains were determined using the API ZYM system (bioMérieux, Marcy-l'Etoile, France) according to the manufacturer's guidelines. Test strips were read after $5 \mathrm{~min}$ as indicated by the manufacturer, and each assay was performed twice to ensure reproducibility.

\subsection{Bacterial DNA Extraction and Sequencing}

The genomic DNA of strains was extracted and purified using the commercial Wizard ${ }^{\circledR}$ Genomic DNA Purification kit (Promega, Madison, WI, USA), following the instructions of the supplier. The whole genomic DNA was sequenced by Macrogen USA (Rockville, MD, USA) using the Illumina MiSeq platform, and 500-bp inserts from paired-end sequencing were utilized in the genomic library. Low-quality reads were trimmed with a quality threshold of Q20; the trimmed reads were then subjected to de novo assembly using the SPAdes assembler [59]. The reads were assembled to 83 (FP211-J200) and 63 (FP105) scaffolds with the 4,110,772 bp and 4,124,333 bp total genomes lengths for each strain, respectively. Genome was annotated using the NCBI Prokaryotic Genome Annotation Pipeline (PGAP) service. In total, 3748 and 3778 coding sequences of strains FP211-J200 and FP105, respectively, were annotated in the NCBI database. The GenBank accession number of the complete genome sequence of FP211-J200 strain is LSHB01000000 [19], and the genome sequence of FP105 strain was registered under the GenBank accession number of JAHTWS000000000.1.

\subsection{Bacterial Identification}

The whole genomic DNA sequences were used to identify the strains by a genome comparison using the PATRIC bioinformatics platform. FP105 and FP211-J200 strains were identified by comparison analysis of 100 single copy genes using the PATRIC server (https:/ / patricbrc.org/app/PhylogeneticTree, accessed on 10 April 2021). As described in PATRIC platform, protein sequences were aligned using MUSCLE, and the nucleotide coding gene sequences were aligned using the Codon_align function of BioPython. A concatenated alignment of all proteins and nucleotides were written to a phylip formatted file, and then a partitions file for RaxML is generated, describing the alignment in terms of the proteins and then the first, second and third codon positions. Support values were generated using 100 rounds of the "Rapid" bootstrapping option of RaxML.

The whole genome sequences of FP105 and FP211-J200 strains were compared with a total of 46 whole genome sequences currently available for related members of the Chryseobacterium clade. 


\subsection{MICS}

The MICs of oxytetracycline of FP105 and FP211-J200 isolates were determined by a microdilution procedure, as recommended by the CLSI guideline M07-A10 [60] and previously described [61]. Conical bottom microplates added with a cation-adjusted Mueller-Hinton broth (Difco Labs, NJ, USA) were inoculated with the antibiotic to obtain final series of two-fold concentrations in the range of $0.0625-512 \mu \mathrm{g} / \mathrm{mL}$, and bacterial suspensions were inoculated in triplicate microplates, delivering approximately $10^{4}$ colonyforming units per well and incubated at $28^{\circ} \mathrm{C}$ for $24 \mathrm{~h}$. The reference strains E. coli ATCC 25,922 and Aeromonas salmonicida ATCC 33,658 were included as quality controls, as was recommended [21]. All assays were performed twice to check the reproducibility of the assay.

\subsection{Molecular Analysis of tet(X) Genes}

The analysis of the tet $(\mathrm{X})$ gene sequences and their genetic environments were performed using the contigs derived from genomic sequencing using the BioEdit 7.2.5 software [62] and subsequent comparison by BLAST computational analysis with the sequences of tet $(\mathrm{X})$ genes carried by Chryseobacterium strains isolated from fishes included in the GenBank database and/or previously reported [16,25].

The modelling of $\operatorname{Tet}(X)$ proteins produced by the studied strains was based on published $\operatorname{Tet}(\mathrm{X})$ from Bacteroides thetaiotaomicron (PDB accession number: $\mathrm{c} 2 \mathrm{xdoC}$ ) using the online server Phyre2 [63]. The substrate-binding domain (light green), the FAD-binding domain (pink), and the C-terminal helix (blue) were displayed, while the open substrateloading channel was marked in a yellow dotted box. In addition, the alignment of the amino acid sequences of $\operatorname{Tet}(X)$ proteins produced by the Chilean Epilithonimonas strains with the sequences of the other $\operatorname{Tet}(X)$ variants found in Flavobacteriaceae from fishes were conducted with Clustal Omega (https://www.ebi.ac.uk/Tools/msa/clustalo/, accessed on 15 June 2021) generating its output with ESPript 3.0 (http:/ / espript.ibcp.fr/ESPript/cgibin/ESPript.cgi, accessed on 15 June 2021) [64]. A secondary structure based on the Tet $(X)$ protein detected in Bacteroides fragilis (PDB number: 4A6N) served as a structure reference.

\section{Conclusions}

In conclusion, the results of this study demonstrated, for the first time, the carriage of the tet $(\mathrm{X})$ gene by bacterial strains isolated from reared rainbow trout affected with Flavobacteriosis in Chilean freshwater salmonid farming and the carriage of this gene by the Epilithonimonas genus. The detection of the tet $(\mathrm{X})$ gene in these representatives of the Chryseobacterium clade reinforces the hypothesis that this taxonomic group may serve as an important environmental reservoir of this gene. Furthermore, the genetic environment of $\operatorname{tet}(\mathrm{X})$ carried by the Epilithonimonas strains is very different to those detected in two Chryseobacterium isolates recovered from fish in South Korea, despite their high amino acid similarity, suggesting the need to gain knowledge of the genetic epidemiology of tet $(\mathrm{X})$ genes carried by fish pathogenic bacteria. Finally, this study demonstrates the carriage of tet $(\mathrm{X})$ genes by two pathogenic bacteria from reared rainbow trout in Chile may become a threat due to the frequent oxytetracycline-based treatment of Flavobacteriosis in Chile. Finally, this study demonstrated the carriage of tet $(\mathrm{X})$ genes by two pathogenic bacteria isolated from farmed rainbow trout in Chile, which may become a threat to the Chilean industry due to the frequent use of oxytetracycline for the treatment of Flavobacteriosis.

Supplementary Materials: The following are available online at https:/ /www.mdpi.com/article/10 .3390 /antibiotics10091051/s1, Figure S1: Alignment of the amino acid sequences of Tet $(X)$ proteins produced by the Chilean Epilithonimonas strains with the sequences of the other Tet $(X)$ variants found in Flavobacteriaceae from fishes, Table S1: Similarity of nucleotide and amino acid sequences of alpha/beta hydrolase flanking the tet $(\mathrm{X})$ gene carried by strains belonging to the Flavobacteriaceae family isolated from fishes, Table S2: Similarity of nucleotide and amino acid sequences of hypothetical protein flanking the $\operatorname{tet}(\mathrm{X})$ gene carried by strains belonging to the Flavobacteriaceae family isolated from fishes. 
Author Contributions: Conceptualization, C.D.M. and C.C.; methodology, C.C. and J.S.; software, C.C. and J.S.; validation, C.C. and C.D.M.; formal analysis, C.C., C.D.M., J.S. and M.C.R.; investigation, C.C. and J.S.; resources, C.D.M., J.S. and C.C.; writing-original draft preparation, C.D.M., M.C.R., J.S. and C.C.; writing-review and editing, C.D.M., C.C., M.C.R. and J.S.; visualization, C.C. and C.D.M.; supervision, C.D.M. and J.S.; project administration, C.D.M. and J.S.; funding acquisition, C.D.M., C.C. and J.S. All authors have read and agreed to the published version of the manuscript.

Funding: This research was partially funded by the Science and Technology National Council (CONICYT) of Chile (grant numbers: 1040924 and 1140330) and NSERC-Discovery grant (RGPIN2018-05942), Canada. C.C. was supported by the Postdoctoral Fund of the Universidad Católica del Norte (grant number: 002).

Data Availability Statement: The whole-genome sequences of FP105 and FP211-J200 strains have been deposited at DDBJ/ENA/GenBank under the accession numbers of JAHTWS000000000.1 and LSHB01000000.1, respectively.

Conflicts of Interest: The authors declare no conflict of interest. The funders had no role in the design of the study; in the collection, analyses, or interpretation of data; in the writing of the manuscript, or in the decision to publish the results.

\section{References}

1. Avendaño-Herrera, R.; Houel, A.; Irgang, R.; Bernardet, J.F.; Godoy, M.; Nicolas, P.; Duchaud, E. Introduction, expansion and coexistence of epidemic Flavobacterium psychrophilum lineages in Chilean fish farms. Vet. Microbiol. 2014, 170, 298-306. [CrossRef] [PubMed]

2. Avendaño-Herrera, R. Proper antibiotics use in the Chilean salmon industry: Policy and technology bottlenecks. Aquaculture 2018, 495, 803-805. [CrossRef]

3. Miranda, C.D.; Godoy, F.A.; Lee, M.R. Current Status of the Use of Antibiotics and the Antimicrobial Resistance in the Chilean Salmon Farms. Front. Microbiol. 2018, 9, 1284. [CrossRef]

4. SERNAPESCA. Informe sobre Uso de Antimicrobianos en la Salmonicultura Nacional Año 2020; Servicio Nacional de Pesca y Acuicultura: Valparaíso, Chile, 2021; 11p. Available online: http://www.sernapesca.cl/sites/default/files/informe_atb_2020.pdf (accessed on 20 April 2021).

5. Roberts, M.C.; Schwarz, S. Tetracycline and Phenicol Resistance Genes and Mechanisms: Importance for Agriculture, the Environment, and Humans. J. Environ. Qual. 2016, 45, 576-592. [CrossRef]

6. Miranda, C.D. Antimicrobial resistance in salmonid farming. In Antimicrobial Resistance in the Environment; Keen, P.L., Montforts, M.H.M.M., Eds.; Wiley-Blackwell: Hoboken, NJ, USA, 2012; Chapter 22; pp. 423-451.

7. Bueno, I.; Travis, D.; González-Rocha, G.; Alvarez, J.; Lima, C.; Benitez, C.G.; Phelps, N.B.D.; Wass, B.; Johnson, T.J.; Zhang, Q.; et al. Antibiotic resistance genes in freshwater trout farms in a watershed in Chile. J. Environ. Qual. 2019, 48, $1462-1471$. [CrossRef]

8. Miranda, C.D.; Zemelman, R. Antimicrobial multiresistance in bacteria from freshwater Chilean salmon farms. Sci. Total Environ. 2002, 293, 207-218. [CrossRef]

9. Miranda, C.D.; Zemelman, R. Bacterial resistance to oxytetracycline in Chilean salmon farming. Aquaculture 2002, $212,31-47$. [CrossRef]

10. Miranda, C.D.; Kehrenberg, C.; Ulep, C.; Schwarz, S.; Roberts, M.C. Diversity of tetracycline resistance genes in bacteria from Chilean salmon farms. Antimicrob. Agents Chemother. 2003, 47, 883-888. [CrossRef] [PubMed]

11. Roberts, M.C.; No, D.; Kuchmiy, E.; Miranda, C.D. Tetracycline resistance gene tet(39) identified in three new genera of bacteria isolated in 1999 from Chilean salmon farms. J. Antimicrob. Chemother. 2015, 70, 619-621. [CrossRef] [PubMed]

12. Yang, W.; Moore, I.F.; Koteva, K.P.; Bareich, D.C.; Hughes, D.W.; Wright, G.D. TetX is a flavin-dependent monooxygenase conferring resistance to tetracycline antibiotics. J. Biol. Chem. 2004, 279, 52346-52352. [CrossRef]

13. Volkers, G.; Palm, G.J.; Weiss, M.S.; Wright, G.D.; Hinrichs, W. Structural basis for a new tetracycline resistance mechanism relying on the TetX monooxygenase. FEBS Lett. 2011, 585, 1061-1066. [CrossRef]

14. Roberts, M.C. Mechanisms of bacterial antibiotic resistance and lessons learned from environmental tetracycline-resistant bacteria. In Antimicrobial Resistance in the Environment; Keen, P.L., Montforts, M.H., Eds.; Wiley-Blackwell: Hoboken, NJ, USA, 2012; pp. 93-121.

15. Fang, L.-X.; Chen, C.; Cui, C.-Y.; Li, X.-P.; Zhang, Y.; Liao, X.-P.; Sun, J.; Liu, Y.-H. Emerging High-Level Tigecycline Resistance: Novel Tetracycline Destructases Spread via the Mobile Tet(X). BioEssays 2020, 42, 2000014. [CrossRef] [PubMed]

16. Verner-Jeffreys, D.W.; Brazier, T.; Perez, R.Y.; Ryder, D.; Card, R.M.; Welch, T.J.; Hoare, R.; Ngo, T.; McLaren, N.; Ellis, R.; et al. Detection of the florfenicol resistance gene floR in Chryseobacterium isolates from rainbow trout. Exception to the general rule? FEMS Microbiol. Ecol. 2017, 93, fix015. [CrossRef] 
17. McBride, M.J. The Family Flavobacteriaceae. In The Prokaryotes: Other Major Lineages of Bacteria and the Archaea; Rosenberg, E., Scheleifer, K.H., DeLong, E.F., Lory, S., Stackebrandt, E., Thompson, F., Eds.; Springer: Berlin/Heidelberg, Germany, 2014; pp. 643-676.

18. O'Sullivan, L.A.; Rinna, J.; Humphreys, G.; Weightman, A.J.; Fry, J.C. Culturable phylogenetic diversity of the phylum “Bacteroidetes" from river epilithon and coastal water and description of novel members of the family Flavobacteriaceae: Epilithonimonas tenax gen. nov., sp. nov. and Persicivirga xylanidelens gen. nov., sp. nov. Int. J. Syst. Evol. Microbiol. 2006, 56, 169-180. [CrossRef] [PubMed]

19. Ayala, M.; Segovia, C.; Rojas, R.; Miranda, C.; Santander, J. Draft genome sequence of Epilithonimonas sp. FP211-J200, isolated from an outbreak episode on a rainbow trout (Oncorhynchus mykiss) farm. Genome Announc. 2017, 5, e00819-17. [CrossRef] [PubMed]

20. Shakéd, T.; Hantsis-Zacharov, E.; Halpern, M. Epilithonimonas lactis sp. nov., isolated from raw cow's milk. Int. J. Syst. Evol. Microbiol. 2010, 60, 675-679. [CrossRef]

21. CLSI (Clinical and Laboratory Standards Institute). Performance Standards for Antimicrobial Susceptibility Testing of Bacteria Isolated from Aquatic Animals, 3rd ed.; CLSI supplement VET04; CLSI Standards Centre: Wayne, PA, USA, 2020.

22. Oh, W.T.; Jun, J.W.; Giri, S.S.; Yun, S.; Kim, H.J.; Kim, S.G.; Kim, S.W.; Han, S.J.; Kwon, J.; Park, S.C. Isolation of Chryseobacterium siluri sp. nov., from liver of diseased catfish (Silurus asotus). Heliyon 2020, 6, e03454. [CrossRef]

23. Kang, D.; Shoaie, S.; Jacquiod, S.; Sørensen, S.J.; Ledesma-Amaro, R. Comparative Genomics Analysis of Keratin-Degrading Chryseobacterium Species Reveals Their Keratinolytic Potential for Secondary Metabolite Production. Microorganisms 2021, 9 , 1042. [CrossRef] [PubMed]

24. Zamora, L.; Fernández-Garayzábal, J.F.; Palacios, M.A.; Sánchez-Porro, C.; Svensson-Stadler, L.A.; Domínguez, L.; Moore, E.R.; Ventosa, A.; Vela, A.I. Chryseobacterium oncorhynchi sp. nov., isolated from rainbow trout (Oncorhynchus mykiss). Syst. Appl. Microbiol. 2012, 35, 24-29. [CrossRef] [PubMed]

25. Jeong, J.-J.; Lee, Y.J.; Pathiraja, D.; Park, B.; Choi, I.-G.; Kim, K.D. Draft genome sequences of Chryseobacterium lactis NCTC11390 ${ }^{\mathrm{T}}$ isolated from milk, Chryseobacterium oncorhynchi $701 \mathrm{~B}-08^{\mathrm{T}}$ from rainbow trout, and Chryseobacterium viscerum $687 \mathrm{~B}-08^{\mathrm{T}}$ from diseased fish. Genome Announc. 2018, 6, e00628-18. [CrossRef]

26. Saticioglu, I.B.; Ay, H.; Altun, S.; Duman, M.; Sahin, N. Flavobacterium turcicum sp. nov. and Flavobacterium kayseriense sp. nov. isolated from farmed rainbow trout in Turkey. Syst. Appl. Microbiol. 2021, 44, 126186. [CrossRef] [PubMed]

27. Zamora, L.; Fernandez-Garayzabal, J.F.; Sanchez-Porro, C.; Palacios, M.A.; Moore, E.R.; Domínguez, L.; Ventosa, A.; Vela, A.I. Flavobacterium plurextorum sp. nov. Isolated from Farmed Rainbow Trout (Oncorhynchus mykiss). PLoS ONE 2013,8 , e67741. [CrossRef]

28. Stine, C.B.; Li, C.; Crosby, T.C.; Hasbrouck, N.R.; Lam, C.; Tadesse, D.A. Draft whole genome sequences of 18 Flavobacterium spp. Genome Announc. 2017, 5, e00865-17. [CrossRef] [PubMed]

29. Bernardet, J.F. Cytophaga, Flavobacterium, Flexibacter and Chryseobacterium infections in cultured marine fish. Fish Pathol. 1998, 33, 229-238. [CrossRef]

30. Loch, T.P.; Faisal, M. Emerging flavobacterial infections in fish: A review. J. Adv. Res. 2015, 6, 283-300. [CrossRef]

31. Zamora, L.; Vela, A.I.; Palacios, M.A.; Sánchez-Porro, C.; Svensson-Stadler, L.A.; Domínguez, L.; Moore, E.R.B.; Ventosa, A.; Fernández-Garayzábal, J.F. Chryseobacterium viscerum sp. nov., isolated from diseased fish. Int. J. Syst. Evol. Microbiol. 2012, 62, 2934-2940. [CrossRef]

32. Zamora, L.; Vela, A.I.; Palacios, M.A.; Domínguez, L.; Fernández-Garayzábal, J.F. First isolation and characterization of Chryseobacterium shigense from rainbow trout. BMC Vet. Res. 2012, 8, 77. [CrossRef]

33. Kämpfer, P.; Fallschissel, K.; Avendano-Herrera, R. Chryseobacterium chaponense sp. nov., isolated from farmed Atlantic salmon (Salmo salar). Int. J. Syst. Evol. Microbiol. 2011, 61, 497-501. [CrossRef] [PubMed]

34. Ilardi, P.; Fernandez, J.; Avendaño-Herrera, R. Chryseobacterium piscicola sp. nov., isolated from diseased salmonid fish. Int. J. Syst. Evol. Microbiol. 2009, 59, 3001-3005. [CrossRef]

35. Ilardi, P.; Avendaño-Herrera, R. Isolation of Flavobacterium-like bacteria from diseased salmonids cultured in Chile. Bull. Eur. Assoc. Fish Pathol. 2008, 28, 176-185.

36. Bernardet, J.-F. Family I: Flavobacteriaceae. In Bergey's Manual of Systematic Bacteriology; Vos, P., Garrity, G., Jones, D., Krieg, N.R., Ludwig, W., Rainey, F.A., Schleifer, K.H., Whitman, W.B., Eds.; Springer: New York, NY, USA, 2011; Volume 4, pp. $106-314$.

37. Nicholson, A.C.; Gulvik, C.A.; Whitney, A.M.; Humrighouse, B.W.; Bell, M.E.; Holmes, B.; Steigerwalt, A.G.; Villarma, A.; Sheth, M.; Batra, D.; et al. Division of the genus Chryseobacterium: Observation of discontinuities in amino acid identity values, a possible consequence of major extinction events, guides transfer of nine species to the genus Epilithonimonas, eleven species to the genus Kaistella, and three species to the genus Halpernia gen. nov., with description of Kaistella daneshvariae sp. nov. and Epilithonimonas vandammei sp. nov. derived from clinical specimens. Int. J. Syst. Evol. Microbiol. 2020, 70, 4432-4450. [CrossRef] [PubMed]

38. Zhu, D.-K.; Luo, H.-Y.; Liu, M.-F.; Zhao, X.-X.; Jia, R.-Y.; Chen, S.; Sun, K.-F.; Yang, Q.; Wu, Y.; Chen, X.-Y.; et al. Various Profiles of tet Genes Addition to tet $(\mathrm{X})$ in Riemerella anatipestifer Isolates from Ducks in China. Front. Microbiol. 2018, 9, 585. [CrossRef] [PubMed]

39. Li, R.; Liu, Z.; Peng, K.; Liu, Y.; Xiao, X.; Wang, Z. Co-occurrence of tet(X) variants in an Empedobacter brevis of shrimp origin. Antimicrob. Agents Chemother. 2019, 63, e01636. [CrossRef] 
40. Cheng, Y.; Chen, Y.; Liu, Y.; Guo, Y.; Zhou, Y.; Xiao, T.; Zhang, S.; Xu, H.; Chen, Y.; Shan, T.; et al. Identification of novel tetracycline resistance gene tet $(X 14)$ and its co-occurrence with tet $(X 2)$ in a tigecycline-resistant and colistin-resistant Empedobacter stercoris. Emerg. Microb. Infect. 2020, 9, 1843-1852. [CrossRef] [PubMed]

41. Zeng, Y.; Dong, N.; Zhang, R.; Liu, C.; Sun, Q.; Lu, J.; Shu, L.; Cheng, Q.; Chan, W.-C.E.; Chen, S. Emergence of an Empedobacter falsenii strain harbouring a tet $(\mathrm{X})$-variant-bearing novel plasmid conferring resistance to tigecycline. J. Antimicrob. Chemother. 2020, 75, 531-536. [CrossRef]

42. Umar, Z.; Chen, Q.; Tang, B.; Xu, Y.; Wang, J.; Zhang, H.; Ji, K.; Feng, Y. The poultry pathogen Riemerella anatipestifer appears as a reservoir for Tet $(X)$ tigecycline resistance. Environ. Microbiol. 2021. [CrossRef]

43. Zhang, R.; Dong, N.; Shen, Z.; Zeng, Y.; Lu, J.; Liu, C.; Zhou, H.; Hu, Y.; Sun, Q.; Cheng, Q.; et al. Epidemiological and phylogenetic analysis reveals Flavobacteriaceae as potential ancestral source of tigecycline resistance gene tet $(\mathrm{X})$. Nat. Commun. 2020, 11, 4648. [CrossRef]

44. Seyfried, E.E.; Newton, R.J.; Rubert, K.F., IV; Pedersen, J.A.; McMahon, K.D. Occurrence of tetracycline resistance genes in aquaculture facilities with varying use of oxytetracycline. Microb. Ecol. 2010, 59, 799-807. [CrossRef] [PubMed]

45. Lin, M.; Wu, X.; Yan, Q.; Ma, Y.; Huang, L.; Qin, Y.; Xu, X. Incidence of antimicrobial-resistance genes and integrons in antibiotic-resistant bacteria isolated from eels and aquaculture ponds. Dis. Aquat. Org. 2016, 120, 115-123. [CrossRef] [PubMed]

46. Gao, P.; Mao, D.; Luo, Y.; Wang, L.; Xu, B.; Xu, L. Occurrence of sulfonamide and tetracycline-resistant bacteria and resistance genes in aquaculture environment. Water Res. 2012, 46, 2355-2364. [CrossRef] [PubMed]

47. Tamminen, M.; Karkman, A.; Lõhmus, A.; Muziasari, W.I.; Takasu, H.; Wada, S.; Suzuki, S.; Virta, M. Tetracycline resistance genes persist at aquaculture farms in the absence of selection pressure. Environ. Sci. Technol. 2010, 45, 386-391. [CrossRef]

48. Xiong, W.; Sun, Y.; Zhang, T.; Ding, X.; Li, Y.; Wang, M.; Zeng, Z. Antibiotics, antibiotic resistance genes, and bacterial community composition in fresh water aquaculture environment in China. Microb. Ecol. 2015, 70, 425-432. [CrossRef]

49. Muziasari, W.I.; Pitkänen, L.K.; Sørum, H.; Stedtfeld, R.D.; Tiedje, J.M.; Virta, M. The resistome of farmed fish feces contributes to the enrichment of antibiotic resistance genes in sediments below Baltic sea fish farms. Front. Microbiol. 2017, 7, 2137. [CrossRef] [PubMed]

50. Saticioglu, I.B.; Duman, M.; Altun, S. Genome analysis and antimicrobial resistance characteristics of Chryseobacterium aquaticum isolated from farmed salmonids. Aquaculture 2021, 535, 736364. [CrossRef]

51. He, T.; Wang, R.; Liu, D.; Walsh, T.; Zhang, R.; Lv, Y.; Ke, Y.; Ji, Q.; Wei, R.; Liu, Z.; et al. Emergence of plasmid-mediated high-level tigecycline resistance genes in animals and humans. Nat. Microbiol. 2019, 4, 1450-1456. [CrossRef] [PubMed]

52. Gasparrini, A.; Markley, J.; Kumar, H.; Wang, B.; Fang, L.; Irum, S.; Symister, C.; Wallace, M.; Burnham, C.; Andleeb, S.; et al. Tetracycline-inactivating enzymes from environmental, human commensal, and pathogenic bacteria cause broad-spectrum tetracycline resistance. Communic. Biol. 2020, 3, 241. [CrossRef] [PubMed]

53. Speer, B.; Bedzyk, L.; Salyers, A. Evidence that a novel tetracycline resistance gene found on two Bacteroides transposons encodes an NADP-requiring oxidoreductase. J. Bacteriol. 1991, 173, 176-183. [CrossRef] [PubMed]

54. Aminov, R. Acquisition and Spread of Antimicrobial Resistance: A tet(X) Case Study. Int. J. Mol. Sci. 2021, 22, 3905. [CrossRef] [PubMed]

55. Cain, K.D.; LaFrentz, B.R. Laboratory maintenance of Flavobacterium psychrophilum and Flavobacterium columnare. Curr. Protoc. Microbiol. 2007, 6, 13B.1.1-13B.1.12. [CrossRef] [PubMed]

56. Buller, N.B. Bacteriological Culture Techniques: Microscopy, Culture and Identification. In Bacteria from Fish and Other Aquatic Animals: A Practical Identification Manual, 1st ed.; Buller, N.B., Ed.; CABI Publishing: Cambridge, MA, USA, $2004 ;$ pp. 83-116.

57. Bernardet, J.-F.; Nakagawa, Y.; Holmes, B. Subcommittee on the taxonomy of Flavobacterium and Cytophaga-like bacteria of the International Committee on Systematics of Prokaryotes. Proposed minimal standards for describing new taxa of the family Flavobacteriaceae and emended description of the family. Int. J. Syst. Evol. Microbiol. 2002, 52, 1049-1070. [CrossRef]

58. Barrow, G.I.; Feltham, R.K.A. Cowan and Steel's Manual for the Identification of Medical Bacteria, 3rd ed.; Cambridge University Press: Cambridge, UK, 1993; 331p.

59. Bankevich, A.; Nurk, S.; Antipov, D.; Gurevich, A.A.; Dvorkin, M.; Kulikov, A.S.; Lesin, V.M.; Nikolenko, S.I.; Pham, S.; Prjibelski, A.D.; et al. SPAdes: A new genome assembly algorithm and its applications to single-cell sequencing. J. Comput. Biol. 2012, 19, 455-477. [CrossRef]

60. CLSI (Clinical and Laboratory Standards Institute). Methods for Dilution Antimicrobial Susceptibility Tests for Bacteria that Grow Aerobically, 10th ed.; Approved Standard M07-A10; CLSI Standards Centre: Wayne, PA, USA, 2015.

61. Concha, C.; Miranda, C.D.; Hurtado, L.; Romero, J. Characterization of Mechanisms Lowering Susceptibility to Flumequine among Bacteria Isolated from Chilean Salmonid Farms. Microorganisms 2019, 7, 698. [CrossRef]

62. Hall, T.A. BioEdit: A User-Friendly Biological Sequence Alignment Editor and Analysis Program for Windows 95/98/NT. Nucleic Acids Symp. Ser. 1999, 41, 95-98. [CrossRef]

63. Kelley, L.A.; Mezulis, S.; Yates, C.M.; Wass, M.N.; Sternberg, M.J. The Phyre2 web portal for protein modeling, prediction and analysis. Nat. Prot. 2015, 10, 845-858. [CrossRef]

64. Robert, X.; Gouet, P. Deciphering key features in protein structures with the new ENDscript server. Nucleic Acids Res. 2014, 42, W320-W324. [CrossRef] [PubMed] 